\title{
Three-dimensional approach to understanding the relationship between the Plio-Quaternary stress field and tectonic inversion in the Triassic Cuyo Basin, Argentina
}

\author{
L. Giambiagi ${ }^{1}$, S. Spagnotto ${ }^{2}$, S. M. Moreiras ${ }^{1}$, G. Gómez ${ }^{3}$, E. Stahlschmidt ${ }^{3}$, and J. Mescua ${ }^{1}$ \\ ${ }^{1}$ IANIGLA, CCT Mendoza, Centro Científico y Tecnológico, Parque San Martín s/n, 5500 Mendoza, Argentina \\ ${ }^{2}$ Departamento de Ciencias Geológicas, Universidad Nacional de San Luis, Argentina \\ ${ }^{3}$ El Trebol S.A. Julio Roca 234, 5500, Mendoza, Argentina
}

Correspondence to: L. Giambiagi (lgiambiagi@mendoza-conicet.gob.ar)

Received: 16 December 2014 - Published in Solid Earth Discuss.: 30 January 2015

Revised: 20 March 2015 - Accepted: 27 May 2015 - Published: 19 June 2015

\begin{abstract}
The Cacheuta sub-basin of the Triassic Cuyo Basin is an example of rift basin inversion contemporaneous to the advance of the Andean thrust front, during the PlioQuaternary. This basin is one of the most important sedimentary basins in a much larger Triassic NNW-trending depositional system along the southwestern margin of the Pangea supercontinent. The amount and structural style of inversion is provided in this paper by a three-dimensional approach to the relationship between inversion of rift-related structures and spatial variations in late Cenozoic stress fields.

The Plio-Quaternary stress field exhibits important N-S variations in the foreland area of the southern Central Andes, between 33 and $34^{\circ} \mathrm{S}$, with a southward gradual change from pure compression, with $\sigma_{1}$ and $\sigma_{2}$ being horizontal, to a strike-slip type stress field, with $\sigma_{2}$ being vertical.

We present a 3-D approach for studying the tectonic inversion of the sub-basin master fault associated with strikeslip-reverse to strike-slip faulting stress regimes. We suggest that the inversion of Triassic extensional structures, striking NNW to WNW, occurred during the Plio-Pleistocene in those areas with strike-slip-reverse to strike-slip faulting stress regime, while in the reverse faulting stress regime domain they remain fossilized. Our example demonstrates the impact of the stress regime on the reactivation pattern along the faults.
\end{abstract}

\section{Introduction}

In the southern Central Andes of Chile and Argentina, basin inversion of Mesozoic or early Cenozoic extensional basins has always been assigned to compressive stress states during the growth of the orogeny (i.e., Uliana et al., 1995; Godoy et al., 1999; Jordan et al., 2001; Charrier et al., 2002; Giambiagi et al., 2003; Mescua and Giambiagi, 2012; Mescua et al., 2014). Across west-central Argentina, inversion of half-grabens has received great attention because of the important economic role played by inversion structures in petroleum trapping (Uliana et al., 1995; Zencich et al., 2008). The oil-bearing Triassic Cuyo Basin (Fig. 1a), located in the foreland region of the Andes between 30 and $34^{\circ} \mathrm{S}$, has been traditionally described as a classical example of Mesozoic rift basins subsequently inverted during the CretaceousQuaternary Andean orogeny (Ramos and Kay, 1991; Legarreta et al., 1992; Ávila et al., 2005; Zencich et al., 2008). This basin is mainly a subsurface feature (Rolleri and Criado Roque, 1968), buried under more than $3000 \mathrm{~m}$ of Cenozoic synorogenic sedimentary cover. It is composed by NWto NNW-oriented fault-bounded narrow and elongated subbasins, filled with siliciclastic continental deposits. One of the largest fault-bounded troughs, the Cacheuta sub-basin (Fig. 1b), was extensively studied, due to its abundant oil accumulations (Rolleri and Fernández Garrasino, 1979; Kokogian and Mancilla, 1989). The great majority of the Cuyo Basin oils were sourced from this sub-basin kitchen to feed the other reservoirs (Zencich et al., 2008). Although the majority of oil-bearing structures have been attributed to in- 

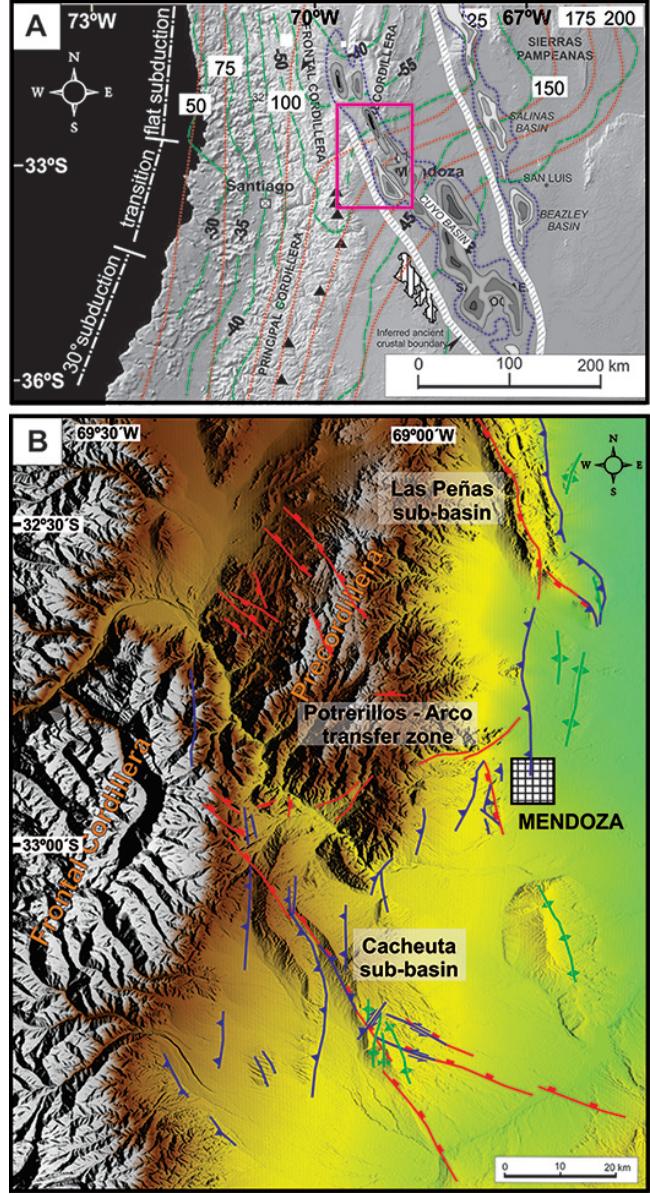

Figure 1. (a) Shaded relief map of the southern Central Andes from 31 to $36^{\circ} \mathrm{S}$, highlighting present-day Andean morphostructural units of the Principal Cordillera , Frontal Cordillera and Precordillera; Sierras Pampeanas; and Triassic rift basins with main sub-basins (shaded depocenters). Green dashed lines indicate the Moho thickness taken from Tassara and Echaurren (2012). Red dashed lines show the depth of the subducting Nazca plate after Cahill and Isacks (1992). White dashed line indicates the extension of the Cuyo Basin at subsurface. The magenta rectangle indicates area of Fig. 1b. Note the location of the study area above the transitional zone between the flat and normal subduction segments. (b) Detailed relief map of the southern termination of the Precordillera range (close to the city of Mendoza, Argentina), the eastern sector of the Frontal Cordillera, and the Cacheuta and Las Peñas sub-basins of the Cuyo Basin. Triassic rift-related structures are in red; Quaternary faults and folds are in black and green, respectively.

version of extensional faults (Dellapé and Hegedus, 1995), there is no general agreement on the deep configuration of the pre-Andean faults, and the degree of tectonic inversion of the sub-basin. Paleozoic inherited weaknesses have been proposed to control the structural style of the sub-basin and its tectonic inversion (Ramos and Kay, 1991). However, it is unclear to which extent these pre-existing planes of weakness contribute to inversion tectonics.

In this paper we argue that a three-dimensional approach is needed to characterize the structural style and amount of rift inversion under a particular stress field pattern. The goals of this article are threefold: (1) characterize the threedimensional structure of the Cacheuta sub-basin, by integrating surface and subsurface data; (2) provide a dynamic model for the Andean thrust front, identifying spatial variations in Plio-Quaternary stress fields that could explain the $\mathrm{N}-\mathrm{S}$ change in the tectonic reactivation styles; and (3) investigate the control of the Plio-Quaternary stress field over the inversion of the Triassic rift basin. The moderate inversion, the good preservation of rift-related and synorogenic strata, and the excellent surface and subsurface geological and geophysical data set make this basin a good candidate to investigate these themes. Our results suggest a direct relationship between the southward gradual change in the foreland stress regime from compression $\left(S_{\mathrm{v}}\right.$ vertical stress $\left.=\sigma_{3}\right)$ to strike-slip $\left(S_{\mathrm{v}}=\sigma_{2}\right)$ and the degree of tectonic inversion of the basin.

\section{Methodology}

Field analysis consisted of detailed geological mapping and structural analysis of the southernmost sector of the Precordillera and the western sector of the Cuyo Basin (Fig. 2). We compiled unpublished subsurface data from oil companies, consisting of 2-D and 3-D seismic reflection data and exploratory and production well data, into a 3-D kinematic model using MOVE academic software (from Midland Valley Inc.). The extent of 2-D and 3-D seismic coverage is marked in Fig. 2. Modeling is based on forward-balanced cross sections. We use a detachment level located at $\sim 12 \mathrm{~km}$ b.s.l., based on previous kinematic reconstructions for the southern Precordillera (10-12 km - Giambiagi et al., 2011) and the eastern sector of the Frontal Cordillera $(12 \mathrm{~km}-$ Giambiagi et al., 2012). This detachment level is in agreement with the (i) seismological data for the thrust front close to the city of Mendoza (Moreiras et al., 2014) and (ii) the most shallow brittle-ductile transitional zone for the study area extracted from the thermomechanical model of Tassara et al. (2014).

The 3-D structural model was created by integrating the digitized geological map draped into a 3-D digital topographic model, surface dip data, well data, cross sections and the extrapolation of fault planes between sections.

The kinematic analysis consisted on the measurement of fault plane-striation data at the main fault planes and their subsidiary fault planes. Slips on individual faults associated with movement along the principal faults recognized in outcrop were integrated to determine the orientation of the principal axes of incremental strain for each structure. Principal strain axes for the main faults have been computed using 


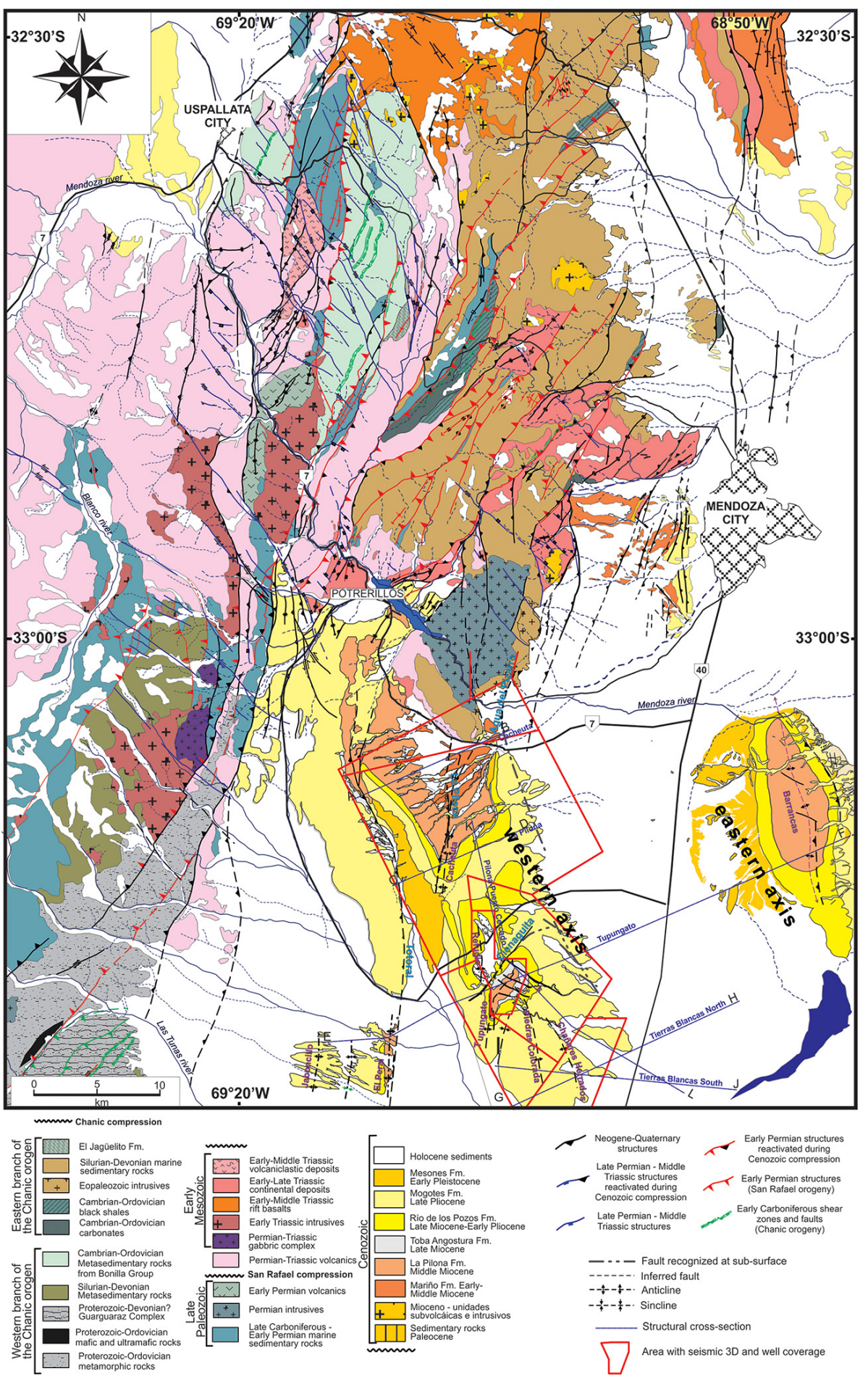

Figure 2. Geological-structural map of the study area $\left(32^{\circ} 30^{\prime}-33^{\circ} 20^{\prime} \mathrm{S}\right)$, showing principal structures recognized at outcrops (different colors in the structural traces represent different deformational phases), modified from Giambiagi et al. (2014). Areas of the Cacheuta, El Peral, Tupungato and Barrancas anticlines were mapped after Irigoyen et al. (2000), García and Casa (2015), Chiaramonte et al. (2000) and Stahlschmidt (1985), respectively. The Cuyo Basin is expressed at surface by two ranges trending NNW, the western and eastern axes, exposing only the Miocene-Pleistocene sedimentary rocks, except in the northernmost sector of the western axis, where basement rocks and Triassic rift units are exposed (Potrerillos area). Red lines show the oil field areas under study. 
the moment tensor summation method as implemented in the FaultKin 4.3 stereonet program of Allmendinger (2001).

For the dynamic modeling, we measured mesoscopic brittle shear faults distributed throughout the study area, except in the southernmost area where no fault-slip data have been found. We focused on data with the best quality of slip-sense indicators, mainly striations and mineral fibers, and thus obtained a robust data set. With this data we performed the paleostress inversion, applying the multiple-slip method implemented in the T-TECTO 3.0 program (http://www2.arnes.si/ $\sim$ jzaloh/t-tecto_homepage.htm), and obtained reduced paleostress tensors with principal axes $\sigma_{1}>\sigma_{2}>\sigma_{3}$, and the stress ratio $D$, capable of explaining the direction of slip on most of the measured faults. We checked that the fault systems in each location could be considered as homogeneous, where all faults have been active at the same time and under the same stress field (Angelier, 1979). For this purpose we used the Gauss paleostress method implemented by Zalohar and Vrabec (2007) in the T-TECTO 3.0 software. The Gauss method takes into account the compatibility between the direction of movement on the fault plane and the resolved shear stress, and the ratio between the normal and shear stress on the fault plane.

After modeling the orientation and spatial disposition of the sub-basin master fault, we carried out slip tendency analysis, using the Stress Analysis Module of Move2014.2. Slip tendency was calculated for the different segments composing the normal faults with the input of the stress tensors obtained for the different structural domains.

\section{Tectonic and geological setting}

The study area is located along the Plio-Quaternary thrust front of the southern Central Andes (Fig. 1b). At the study segment $\left(32-34^{\circ} \mathrm{S}\right)$, the seismically active front exhibits a pronounced along-strike segmentation, coincident with the transitional zone between the Pampean/Chilean flat-slab segment $\left(28-32^{\circ} 30^{\prime} \mathrm{S}\right)$ and the normal-subduction segment (south of $34^{\circ} \mathrm{S}$ ). This segmentation is reflected in important variations in style and amount of shortening, width of the Andean orogeny, and mean topographic uplift (Jordan et al., 1983; Ramos et al., 2002; Giambiagi et al., 2012). Along the flat-slab domain, the Precordillera and Pampean ranges are being actively uplifted with seismicity dominated by reverse faulting mechanisms (Alvarado et al., 2005; Ahumada and Costa, 2009; Schmidt et al., 2011, INPRES catalog). South of $33^{\circ} 30^{\prime} \mathrm{S}$, the normal-subduction domain is characterized by the uplift of San Rafael basement block with small horizontal shortening (Ramos and Folguera, 2005). Between these two domains, a transitional zone $\left(32^{\circ} 30^{\prime}-33^{\circ} 30^{\prime} \mathrm{S}\right)$ shows an abrupt termination at $\sim 33^{\circ} \mathrm{S}$ of the Precordillera and Sierras Pampeanas ranges and moderate inversion of the Cacheuta sub-basin (Fig. 1b).

The Cuyo Basin forms part of a much larger depositional system along the southwestern margin of the Pangea super- continent, associated with the pre-breakup stage of Gondwana (Uliana and Biddle, 1988). During the beginning of this period, between the late Permian and the Early Triassic, a widespread magmatic event is represented by the Choiyoi Group volcanics and intrusives (Llambías et al., 2003). The extensional regime continued during Triassic times and led to the development of a series of rift systems, with overall NNW trend, formed along the southwestern margin of Gondwana (Charrier, 1979; Uliana et al., 1995).

The Triassic Cuyo Basin has an overall NNW trend and two main subsidence axes (Fig. 2). Its more than $2700 \mathrm{~m}$ of siliciclastic continental sediments (Kokogian et al., 1993) were deposited over, and partially interfingered with, the extensive silicic pyroclastic and volcanic deposits of the Choiyoi Group (Rolleri and Criado Roque, 1968). The western axis contains the Cacheuta, La Pilona, Estructura Intermedia, Refugio, Tupungato, Piedras Coloradas, Chañares Herrados and Puesto Pozo Cercado oil fields (Fig. 3); the eastern one involves the Barrancas, La Ventana and Vizcacheras oil fields, while the Tierras Blancas and Ugarteche fields are located in the area "between axes" (Moratello, 1993).

The synrift deposition started in the Middle Triassic ( $\mathrm{Za}$ vattieri and Prámpano, 2006) and consist of alluvian-fan conglomerates (Río Mendoza Formation), fluvial sandstones interbedded with shales and pyroclastic deposits corresponding to ephemeral stream and playa-lake deposits (Las Cabras Formation), braided fluvial deposits (Potrerillos Formation), and lacustrine deltas and bituminous lacustrine basinal deposits (Cacheuta Formation). The sag stage is represented by fluvial red beds (Río Blanco Formation). These deposits are well exposed in the northernmost sector of the Cacheuta subbasin, in the Potrerillos locality (Fig. 2).

The Cacheuta sub-basin is composed by the Cacheuta and Refugio-Tupungato half-grabens, formed during the initial stage of continental rifting, and controlled by movements along the east-dipping Higuerita and Anchayuyo Norte faults, respectively (Fig. 3). During the synrift climax stage, these half-grabens were connected to a broad depocenter filled with up to $450 \mathrm{~m}$ of mostly lacustrian and deltaic deposits of the Cacheuta Formation. This phase was followed by a period of regional subsidence attributed to thermal decay (Kokogian and Mancilla, 1989; Dellapé and Hegedus, 1995).

In the late Early Cretaceous the extensional period was terminated and a major plate tectonic reorganization took place (Mpodozis and Ramos, 1989). But it was not until the early Miocene that this region started to receive synorogenic sediments (Mariño Formation) from the Aconcagua fold and thrust belt (Irigoyen et al., 2000; Giambiagi et al., 2003). Shortening progressed to the east, uplifting the Frontal Cordillera during the late Miocene (La Pilona, Tobas Angostura and Río de los Pozos formations) and Precordillera in the late Pliocene (Irigoyen et al., 2000; Giambiagi et al., 2003; Hoke et al, 2015). 


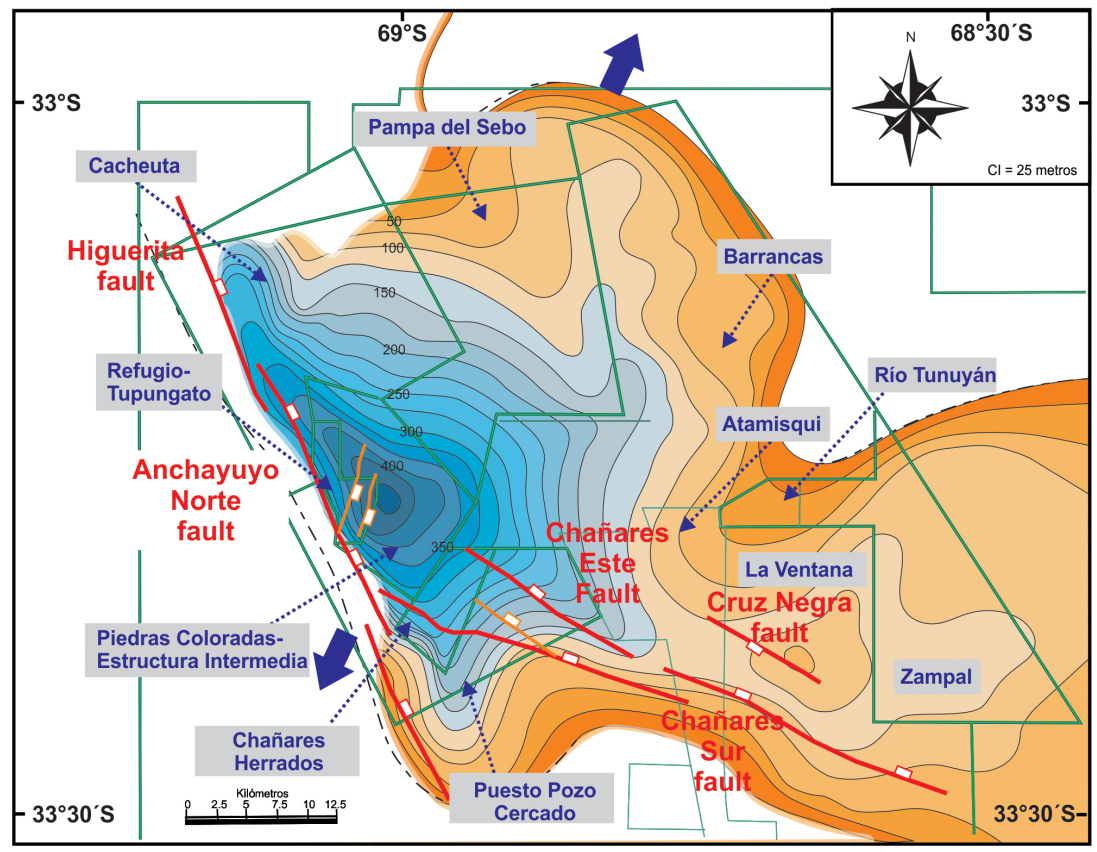

Figure 3. Thickness map of the Cacheuta Formation (Triassic lake deposits representing the climax of synrift) modified from Jones (1992). Notice the Anchayuyo Norte fault corresponds to the maximum thicknesses of this unit. Blue arrows represent the direction of extension during the Triassic (after Giambiagi et al., 2011). Green polygons are oil field areas (names in blue) covered with 3-D seismic data.

Plio-Pleistocene synorogenic sediments derived from the Frontal Cordillera and the Precordillera (Mogotes and Los Mesones formations) are nowadays involved in the active thrust front. This front is located in the Barrancas anticline (Chiaramonte et al., 2000) where the 1985 Mendoza earthquake had its epicenter, while in the southern sector it is located in the Jaboncillo and El Peral anticlines (García and Casa, 2015), more than $40 \mathrm{~km}$ west of the Barrancas anticline (Fig. 2).

The filling of the foreland basin with more than $3000 \mathrm{~m}$ of continental deposits on top of the former Cuyo rift basin created the conditions for oil maturation (Uliana et al., 1995). The basin became involved in the Andean thrust front during the late Pliocene with the foreland advance of the deformation, uplifting and deforming the Neogene strata and exhuming the Triassic sedimentary rocks in the northernmost sector of the Cuyo Basin. This advance of the thrust front occurred concomitant and after the deposition of the conglomerates of the Mogotes Formation (Irigoyen et al., 2000; Chiaramonte et al., 2000; García and Casa, 2015).

\section{Structural setting}

The Precordillera is uplifted by a fault system with similar strike and opposite downward dip (Fig. 2), which can be structurally divided into western and eastern domains (Folguera et al., 2001; Giambiagi et al., 2011). Contractional deformation in the western domain is transferred southward into the La Carrera fault system of the Frontal Cordillera
(Caminos, 1965; Casa et al., 2010; Giambiagi et al., 2014). Thrust fault displacement in the eastern domain abruptly decreases south of the Mendoza River, and deformation is transferred into two regions: the Cacheuta and Barrancas anticlines. These two regions are aligned with the western and eastern axes of the Cuyo Basin, respectively. In the western axis, the perfect alignment of the Plio-Quaternary contractional structures with the Tupungato half-graben is conspicuous (Figs. 1b and 3). In this study area, the structural data fit into three deformational patterns, allowing us to divide the area into three structural domains: northern, central and southern domains (Fig. 4).

\subsection{Exposed faults}

Three main Plio-Quaternary faults and one fault system were recognized during fieldwork: the Totoral, La Pilona and Cienaguita faults and the Agua del Pizarro fault system (Figs. 4 and 5). The Totoral fault, running northward from the El Peral anticline for more than $40 \mathrm{~km}$, is a westdipping, thin-skinned thrust which repeats the Neogene strata and affects the Pleistocene deposits (García and Casa, 2015) (Fig. 5).

The La Pilona fault is a west-dipping, $12 \mathrm{~km}$ long thrust, affecting the Miocene to late Pliocene strata but covered by the middle to late Pleistocene deposits. This indicates a late Pliocene to lower Pleistocene age of movement (Fig. 5a-c). At subsurface, it does not affect the Triassic deposits, allowing us to propose the same shallow detachment level for 


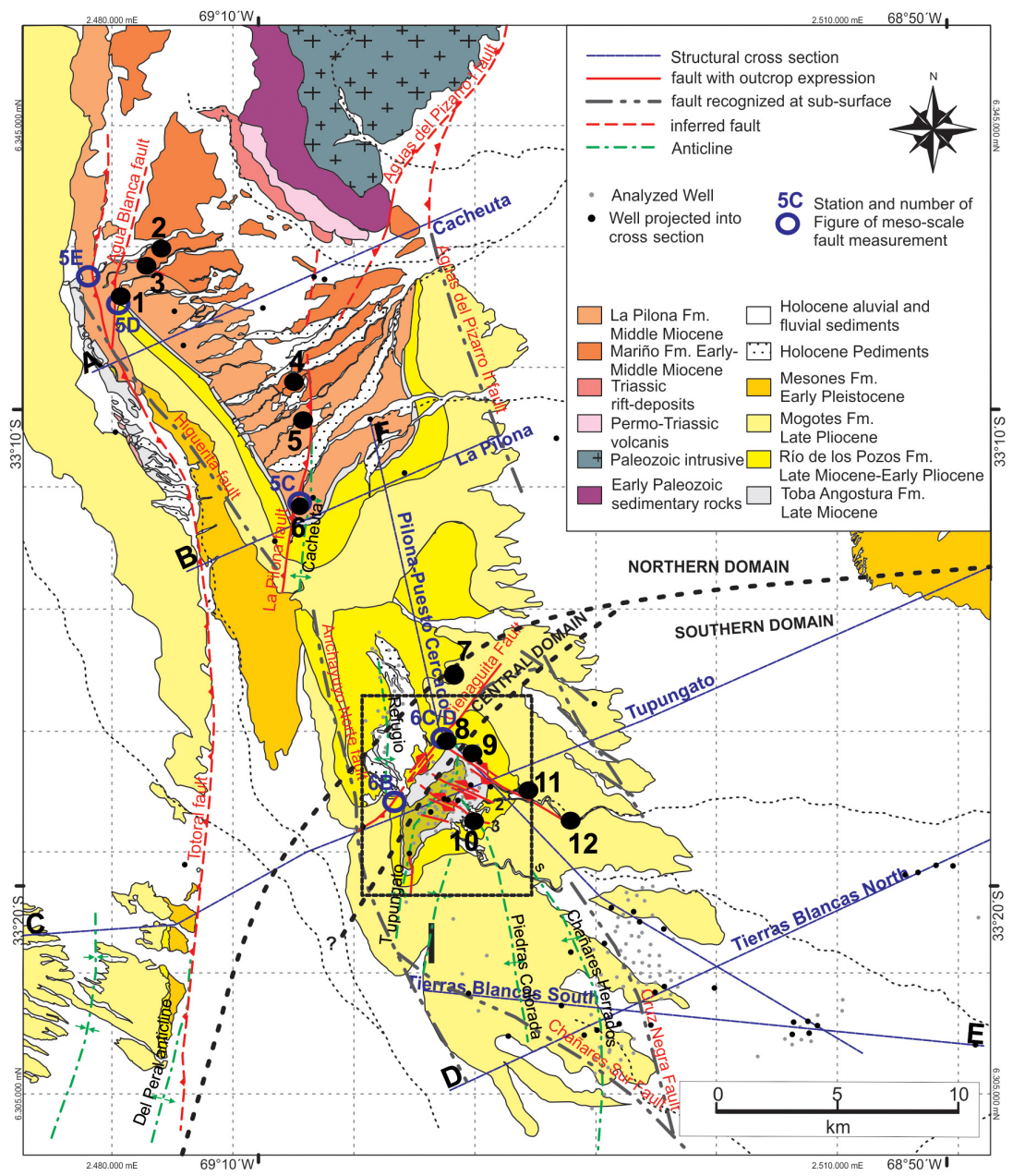

Figure 4. Geological map of the western axis of the Cuyo Basin, with the development of the Cacheuta sub-basin at subsurface. See location in Fig. 2. The area is divided into three structural/kinematic domains: northern, central and southern. Blue open circles are locations of kinematic measurements of major and second-order faults (Figs. 5 and 6). Black dots with numbers correspond to locations of mesoscopic fault-slip measurement station for the dynamic analysis. Box corresponds to Fig. 7. Blue lines indicate traces of cross sections. Names in red and black correspond to main faults and folds of the western axis, respectively.

the Totoral and La Pilona faults. Displacement decreases towards both the south and north. In the Cacheuta cross section (Fig. 5a), the fault achieves $0.8 \mathrm{~km}$ of minimum horizontal shortening, while in the La Pilona cross section (Fig. 5b) it corresponds to a thrust with $1.3 \mathrm{~km}$ of shortening (see Supplement A).

Cross-cutting relationships indicate that the Totoral fault, and a splay fault named Agua Blanca, developed after the Cacheuta anticline, but the La Pilona fault was generated before. This suggests that the shallow and deeper detachments were active simultaneously during the Plio-Pleistocene. In this northern domain, fault-slip data of the major faults indicate a WNW horizontal shortening and vertical extension (Fig. 5c-e).

The Agua del Pizarro fault system is a major contractional structure uplifting the Paleozoic basement on top of the Neogene and Quaternary deposits (Fig. 5). It is composed of a main west-dipping thrust and several splay faults with a smaller amount of shortening. One of these splays affects Pleistocene conglomerates, indicating a Quaternary age of movement. Fault displacements associated with this system are largest in the north and diminish toward the south.

The Cienaguita fault is a SE-dipping structure with dextral-reverse oblique displacement, cropping out in the central domain (Figs. 6 and 7). It affects the Neogene to lower Pleistocene deposits. At subsurface, it places the Triassic strata on top of the Neogene deposits (Fig. 6a). Associated synthetic and antithetic faults can be recognized close to the Tupungato oil field (Fig. 6b-d).

To the south of the Cienaguita fault, a series of NNWto NW-trending faults - named Agua de las Avispas, Calabozo and Angostura - can be observed and measured at the creeks of the same name (Fig. 7). They have been mapped as cross-cutting the Tupungato anticline and affecting the lower 

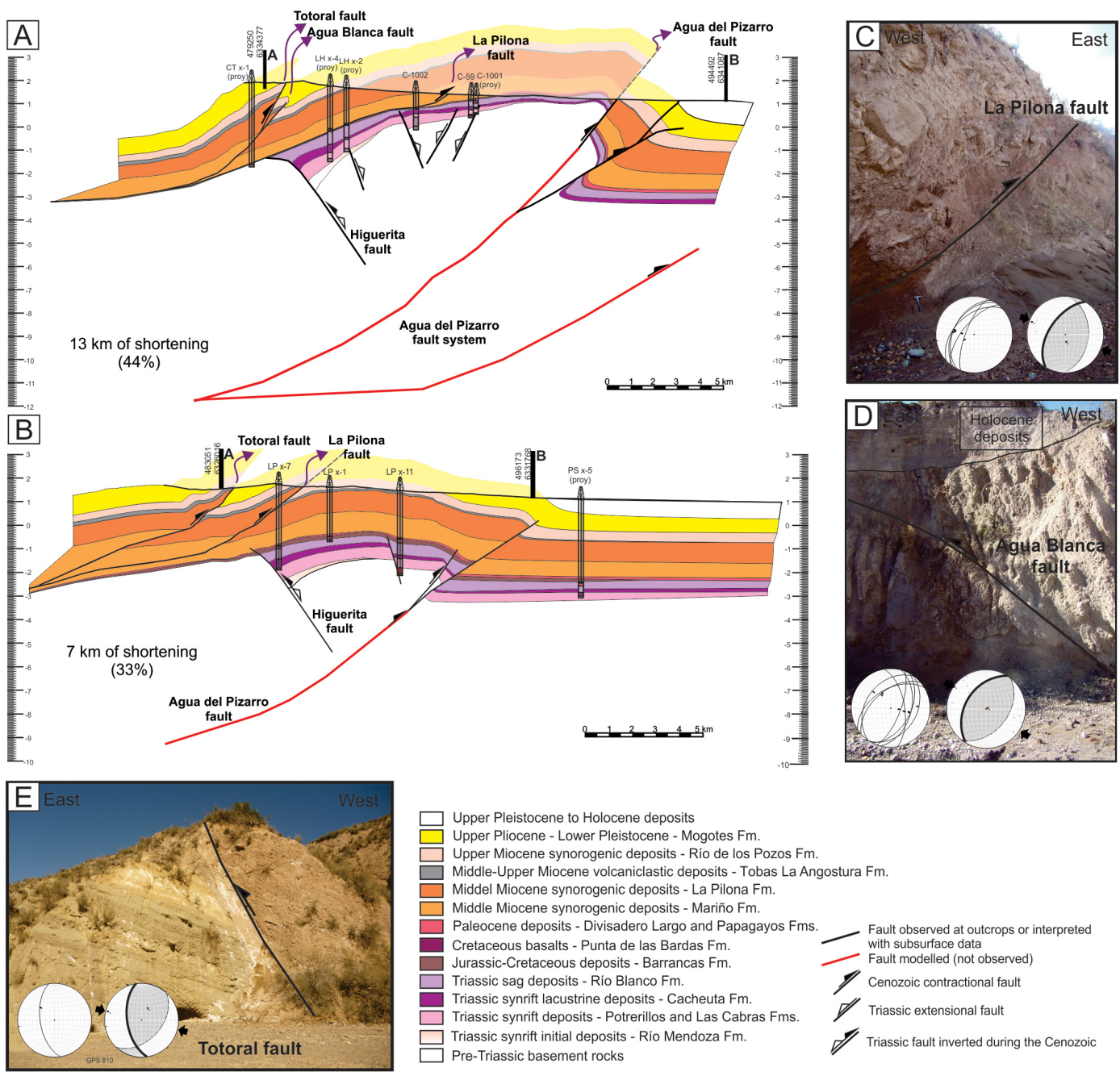

Figure 5. Cacheuta (a) and La Pilona (b) cross sections. See location at Fig. 4. (c) Photograph looking north and kinematic data of the La Pilona fault. Data were taken along the La Pilona cross section. (d) Photograph looking south and kinematic data of the Agua Blanca fault, close to the Cacheuta cross section. (e) Photograph looking south and kinematic data of the Totoral fault.

Pleistocene deposits (Stahlschmidt, 1985). These subparallel structures correspond to $3-5 \mathrm{~km}$ long, subvertical sinistral strike-slip faults with a small amount of displacement between 50 and $100 \mathrm{~m}$. Fault-slip data from these faults and subsidiary mesoscopic faults indicate W-E shortening and N-S extension (Fig. 7).

\subsection{Exposed folds}

Five main folds affect the western axis of the Cuyo Basin (Fig. 4): the Cacheuta, Refugio, Tupungato, Piedras Coloradas and Chañares Herrados anticlines. The Cacheuta anticline has a NNE-trending axis moderately plunging towards the south. To the north, close to the Mendoza River, it corresponds to a highly asymmetrical east-vergent fold, associated with the Aguas del Pizarro fault system (Fig. 5a). Southward, the fold turns into a symmetrical fold (Fig. 5b), decreasing tightness until the structure disappears southward. Horizon- tal shortening is transferred southeastward from the southern tip of the Cacheuta anticline hinge to the northern tip of the Refugio anticline hinge.

The Refugio and Tupungato anticlines have the same trend of the Cacheuta anticline and affect the upper Miocene to lower Pleistocene synorogenic deposits (Fig. 4). The Tupungato anticline has a curved axis close to the Cienaguita fault (Fig. 7a; Stahlschmidt, 1985), and it is inferred to be associated with the oblique-reverse movement of this fault.

The southernmost folds are the Piedras Coloradas and Chañares Herrados anticlines (Fig. 4). At surface they are open symmetric folds affecting the Neogene to lower Pleistocene synorogenic deposits. As we will discuss in the following section, these structures are interpreted to be genetically related to movement along buried strike-slip faults. 

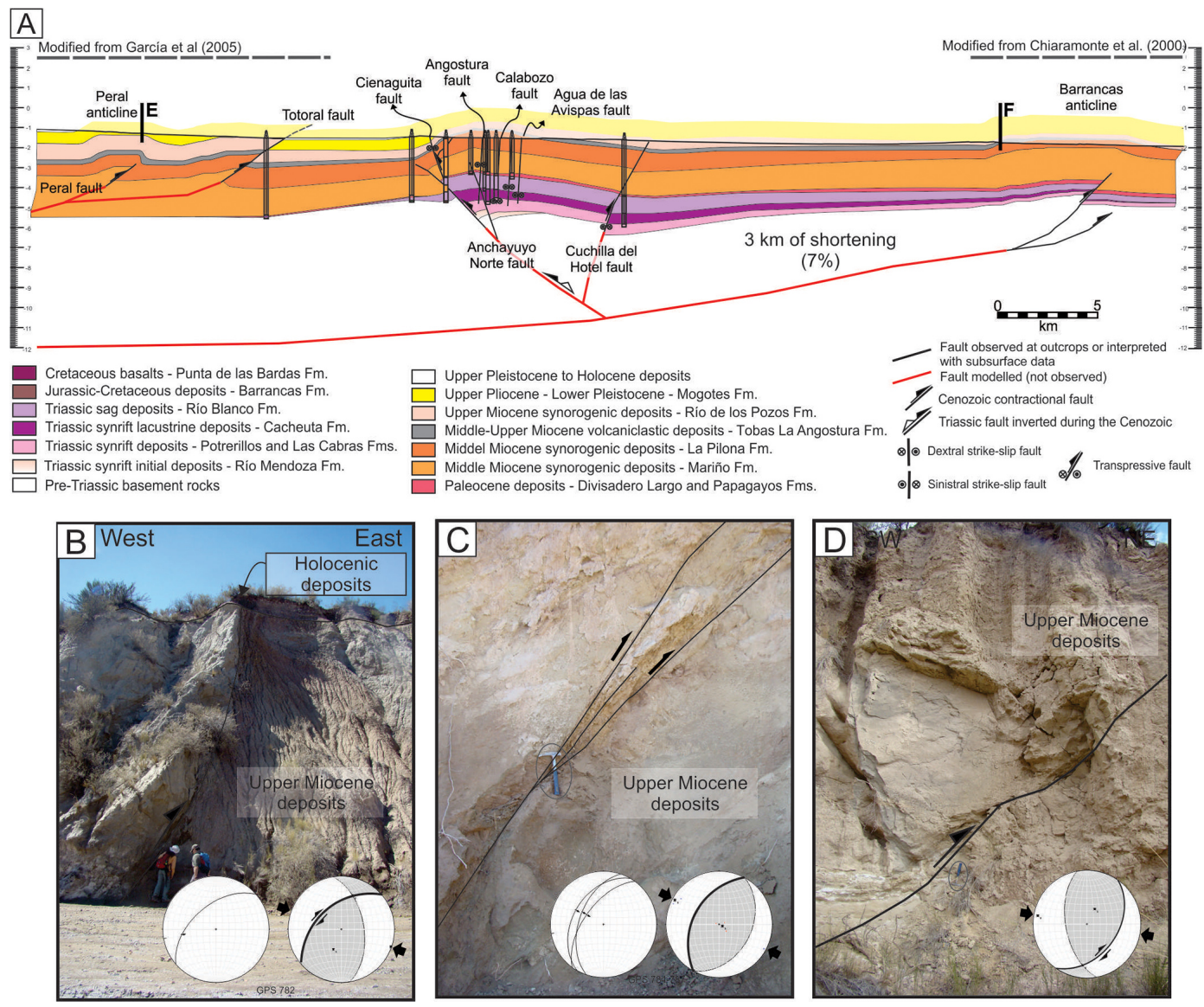

Figure 6. (a) Tupungato cross section. See location at Fig. 4. (b-d) Photographs of the main and subsidiary planes of the Cienaguita fault, with kinematic indicators of a reverse/strike-slip movement (see locations in Fig. 4).

\subsection{Interpretation of subsurface structures}

The interpretation of seismic and well data allows us to identify two main Triassic synrift structures: the Higuerita and Anchayuyo Norte high-angle faults (Fig. 3). The Higuerita fault is an ENE-dipping normal fault accommodating Triassic extensional displacement. Wells located in its hanging wall clearly indicate important thickness variations on the order of $1000 \mathrm{~m}$ and the existence of a wedge geometry of the synrift and sag deposits. There is no evidence at subsurface that this fault has been inverted during the Cenozoic shortening.

The ENE-dipping Anchayuyo Norte fault does not crop out, but it is manifested at the surface by the open folds of the Neogene to Pleistocene strata (Figs. 6a and 8). Well data indicate a repetition of the Triassic sag deposits and the uplift of these strata over the Miocene deposits.

The NE-striking Refugio fault is parallel to the Cienaguita fault (9). At surface a broad fold of the Miocene to Pliocene strata over the fault is recognized. At subsurface, it has been interpreted as a dextral strike-slip-reverse fault with associated splay faults, forming a flower structure.
In the southern sector of the study area, two faults, Chañares Sur and Cruz Negra, are the main structures at subsurface (Fig. 10a). These faults have NW to WNW strikes and delineate a graben filled with Triassic synrift and sag deposits (Fig. 10b). Seismic data suggest that they present a dip-slip offset for the Triassic with a minor strike-slip component, suggesting that they correspond to Triassic normal faults slightly reactivated as sinistral strike-slip faults (Fig. 11). On the other hand, time slices close to the top of the Mesozoic strata indicate a sinistral strike-slip movement without normal offset. The most remarkable feature in this sector is the decoupling effect recognized in 3-D subsurface data between the faulted Triassic strata and the folded MesoCenozoic deposits (Fig. 11).

No contractional structure is observed or interpreted at depth in this southern strike-slip domain. The Chañares Herrados and Piedras Coloradas anticlines are interpreted as related to sinistral strike-slip movement along the Chañares Sur and Cruz Negra faults, transferred upward into folds disposed at an angle of $20-30^{\circ}$ with respect to the deep faults (Figs. 10 and 11). 

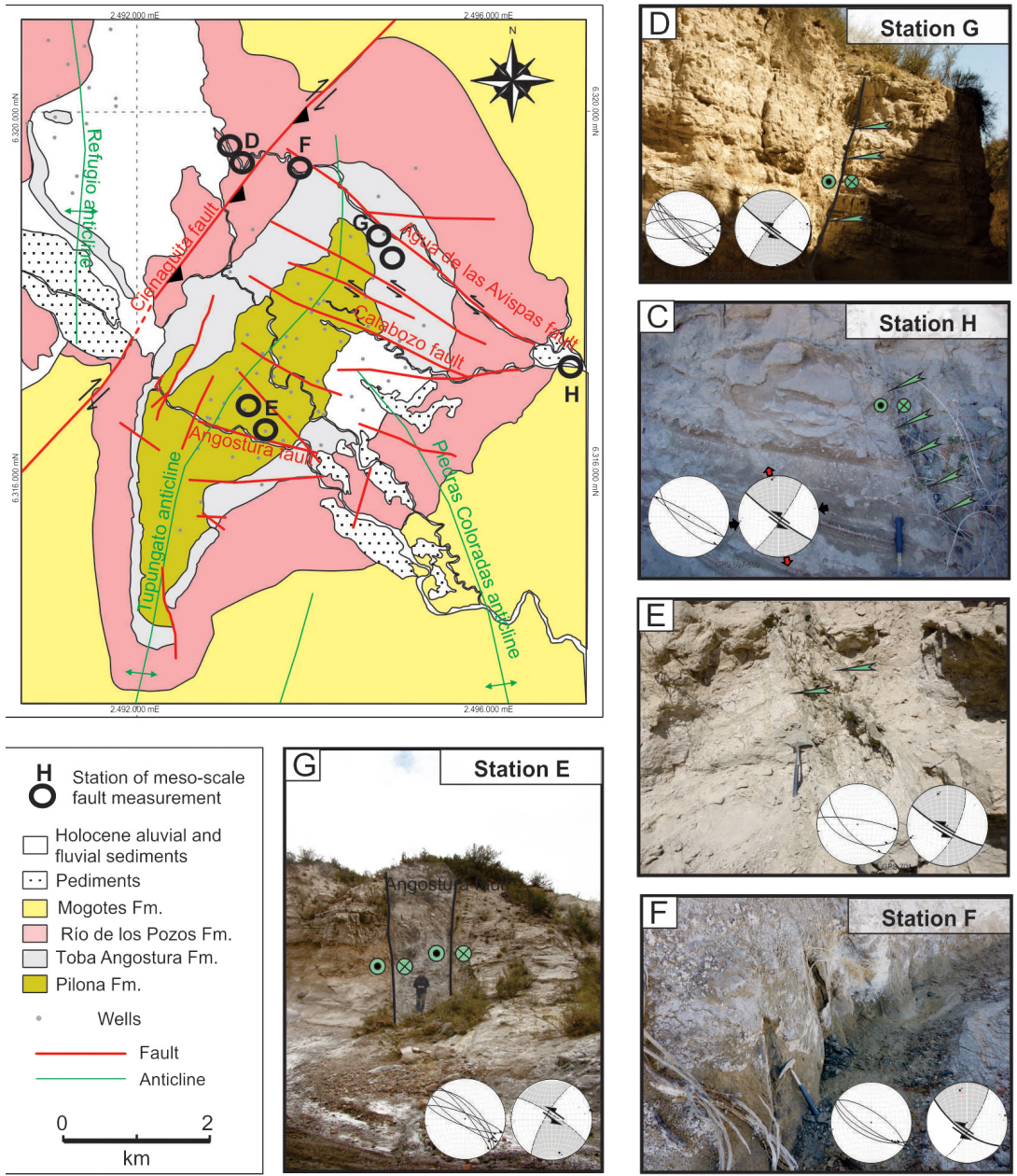

Figure 7. (a) Detailed geological map of the Refugio-Tupungato oil field. Modified after Stahlschmidt (1985). See location in Fig. 4. (b-f) Examples of NW-trending sinistral strike-slip mesoscopic faults affecting the Tupungato anticline area at the different measurement stations.

\section{Dynamic analysis}

We performed dynamic analysis with the mesoscopic faults collected at different stations (Fig. 12) and obtained 12 well-constrained (paleo)stress tensor solutions for the upper Pliocene to the Middle Pleistocene (see Supplement B). The stress compatibility analysis performed with the Gauss method, which takes into account both the angular misfit between the resolved shear stress and direction of movement on the fault plane, and the radio between normal and shear stress on that fault plane (Zalohar and Vrabec, 2007) show homogeneous results. This consistency allows us to skip the most critical point in fault-slip analysis, which is separating heterogeneous sets of data into homogeneous subsets.

Four stress states have been determined (see Supplement B) with a clear spatial distribution (Fig. 12): (i) reverse faulting stress regime with WNW average azimuth of $\sigma_{1} / \mathrm{SH}_{\max }$ (stress tensors 1-7); (ii) strike-slip/reverse faulting regime with $\mathrm{E}-\mathrm{W}$ average azimuth of $\sigma_{1} / \mathrm{SH}_{\max }$ and $\mathrm{N}-$
$\mathrm{S}$ azimuth of $\sigma_{3} / \mathrm{Sh}_{\min }$ (stress tensors 7 and 8); (iii) strikeslip faulting regime with $\mathrm{E}-\mathrm{W}$ average azimuth of $\sigma_{1} / \mathrm{SH}_{\max }$ and $\mathrm{N}-\mathrm{S}$ of $\sigma_{3} / \mathrm{Sh}_{\min }$ (stress tensors 9-11); and (iv) normal faulting regime with $\mathrm{N}-\mathrm{S}$ azimuth of $\sigma_{3} / \mathrm{Sh}_{\min }$ (stress tensor 12). In the northern domain, results consistently indicate a compressional regime with WNW-oriented $\sigma_{1} / \mathrm{SH}_{\max }(\mathrm{Az}$ $\left.106-125^{\circ}\right)$. In the southern domain, results indicate a strikeslip faulting regime with $\mathrm{E}-\mathrm{W}$-orientated $\sigma_{1} / \mathrm{SH}_{\max }(\mathrm{Az} 73-$ $84^{\circ}$ ). In the southernmost sector of the study area, strike-slip and extensional stress tensors were recorded. No chronological evidence was found to distinguish normal from strike-slip faults. These two types of stress tensors are consistent with a single heterogeneous stress field and hence can be interpreted as the result of local permutation of $\sigma_{1}$ and $\sigma_{2}$ principal stress axes. Moreover, the normal faulting regime is detected near the southeast termination of the Agua de las Avispas fault (Station H in Fig. 6). The close spatial interaction of strikeslip and normal faulting in this location and the absence of obvious overprinting lead us to propose that this sector of the 


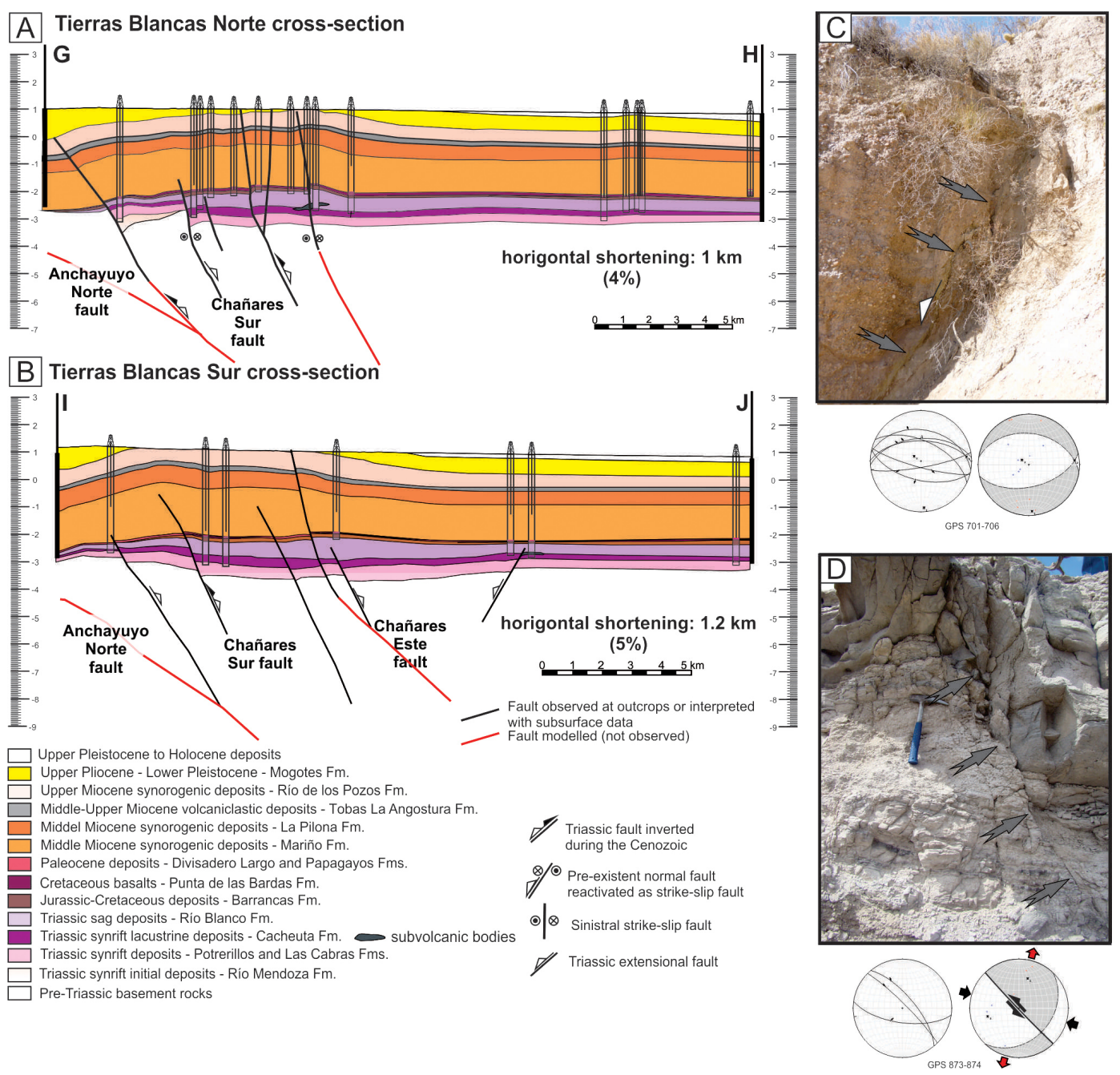

Figure 8. Tierras Blancas Norte (a) and Tierras Blancas Sur (b) cross sections. See location in Fig. 4. (c) Photograph looking east of a mesoscopic normal fault and kinematic data measured along cross sections. (d) Photograph looking SE and kinematic data of the T7 fault, mapped by Stahlschmidt (1985) as a normal-strike-slip fault.

study area operated as a sinistral strike-slip-normal regime with local $\sigma_{1} / \sigma_{2}$ permutation.

Values of stress ratio $D=\left(\sigma_{2}-\sigma_{3}\right) /\left(\sigma_{1}-\sigma_{3}\right)$ are mainly close to 0.5 in both the northern and southern domains, indicating the prevalence of triaxial stress states $\left(\sigma_{1}>\sigma_{2}>\sigma_{3}\right)$. In the central domain, the stress ratio is close to 0.25 , suggesting the existence of a nearly pure uniaxial compressional stress field $\left(\sigma_{1}>\sigma_{2}=\sigma_{3}\right)$. This suggests a local $\sigma_{2}-\sigma_{3}$ permutation due to a tendency of progressive change from compressional stress regime in the north to a strike-slip regime in the south.

The compressive stress regime in the northern domain is well documented by focal mechanisms (Fig. 12), suggesting movement along NNW- to NNE-trending reverse faults with ENE orientation of $\mathrm{SH}_{\max }$. In the central and southern domains, only few focal mechanisms have been calculated indicating strike-slip movement along NE- or NW-trending faults in accordance with our Plio-Pleistocene paleostress tensors.

\section{Slip tendency analysis}

The potential of a normal fault to reactivate under a subsequent deformational event is a function of its frictional characteristics and the ratio of resolved shear stress to resolved normal stress on a surface (Morris et al., 1996). Faults where shear stresses are high enough to overcome the frictional resistance are those well-oriented for reactivation (see Supplement C). The value of the slip tendency for a fault segment is a measure for its likelihood to fail under the given stress field, and it depends only upon the ratios of the principal stresses and the orientation of the fault segments. Higher slip tendency values for a given fault segment imply higher probability of slip.

Classical slip tendency analyses constrain the spatial pattern of fault reactivation by assuming that slip occurs in the direction of the resolved shear stress if it is larger than 


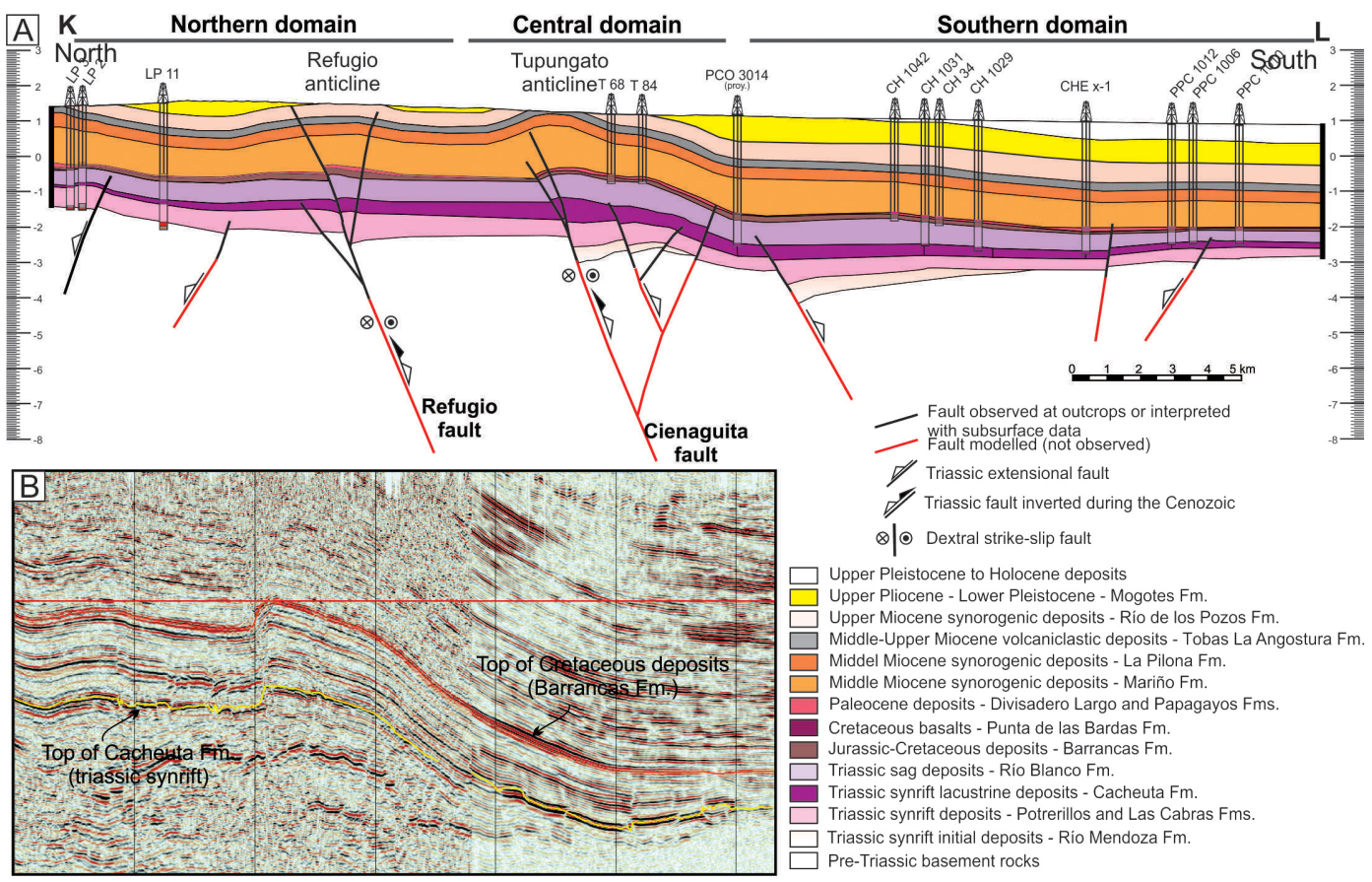

Figure 9. (a) The Pilona-Puesto Pozo Cercado regional N-S cross section, running from the northern to the southern domains. See location in Fig. 4. Observe the abrupt change in topographic and structural level (basement-cover interface) in the central domain, reflecting the effect of more horizontal shortening in the north than in the south. (b) Arbitrary seismic line obtained from 3-D seismic data running along the Pilona-Puesto Pozo Cercado cross section.
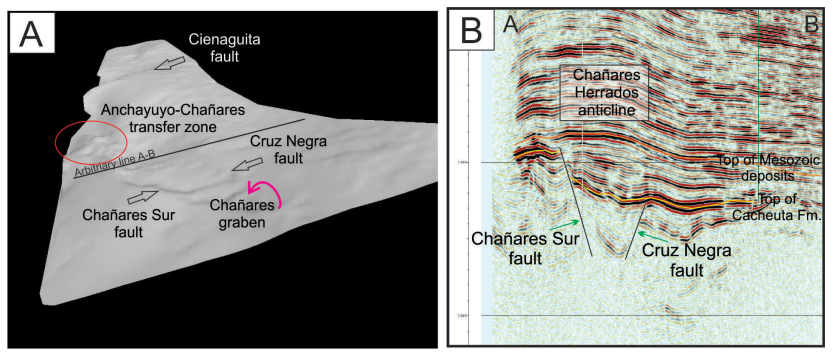

Figure 10. Top of the Cacheuta Formation surface (synrift-sag transition) converted to depth (a) and arbitrary line A-B (b). Notice the Chañares Sur and Cruz Negra faults preserved as Triassic extensional structures, below the Meso-Cenozoic contact. A region with more complicated deformation is named the Anchayuyo-Chañares transfer zone, and it is interpreted as a Triassic transfer zone between the Anchayuyo Norte master fault and Chañares Sur extensional fault. The Chañares Herrados anticline is interpreted as a fold generated by strike-slip reactivation of the Chañares Sur fault.

the frictional resistance of the fault (Morris et al, 1996). In our case study, with the evidences of fault segments reactivated and non-reactivated, we investigate under which conditions of frictional coefficients, stress radio $\left(\sigma_{1} / \sigma_{3}\right)$ and pore pressure the central and southern segments were reactivated, while the northern segment remains unreactivated (see Supplement C).
We consider faults to be cohesionless, frictional coefficients ranging from 0.4 to 0.8 and values of pore pressure between hydrostatic to overpressure (20, 40 and $60 \mathrm{MPa})$. On the Anchayuyo Norte 3-D fault segment surfaces, the resolved shear and normal stresses are calculated using the Plio-Quaternary stress tensor and the local normal vector of the fault segment at three different locations: northern, central and southern domains. We assume that $\sigma_{v}$ has a constant magnitude and represents the vertical overburden stress. This magnitud corresponds to $\sigma_{3}$ in the northern and central domains, and to $\sigma_{2}$ in the southern domain.

Slip tendency of the modeled fault segments is lower for compressive stress tensor than for strike-slip faulting ones, indicating that reactivation would be easier if the $\sigma_{2}$ were vertical (Fig. 13). The results demonstrate the impact of changing the local stress fields on the reactivation pattern along pre-existing synrift faults. The high slip tendency values on the fault segments located in the southern domain, which is dominated by a strike-slip regime, indicate that the master fault is suitably oriented to the strike-slip faulting stress field under either slightly elevated pore pressure or reduced frictional coefficients, or a combination of both factors. The low calculated slip tendency on the northern sector of the master fault indicates that it is not optimally oriented to the compressive stress field; therefore reactivation is unlikely to occur. 


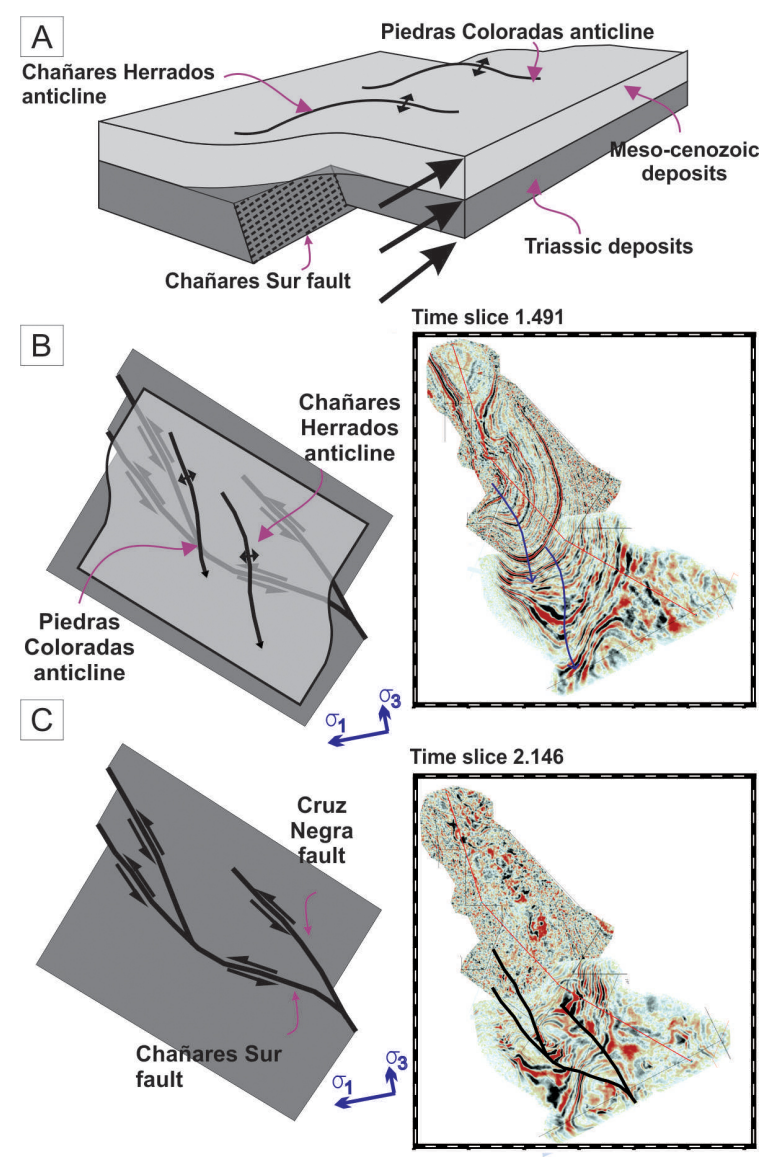

Figure 11. (a) Kinematic interpretation of the Chañares Herrados and Piedras Coloradas anticlines. These faults were developed from sinistral movement of the pre-existing Chañares Sur and Cruz Negra normal faults, and the uncoupling between Triassic deposits and the Meso-Cenozoic cover. This uncoupling is clearly observed at different levels of depth in the 3-D seismic data. (b) Time slice $1.491 \mathrm{~ms}$ from 3-D seismic data and interpretation of the genesis of the anticline. (c) Time slice $2.146 \mathrm{~ms}$ and interpretation of pre-existing Triassic normal faults reactivated as sinistral strike-slip ones.

\section{Discussion: relationship between basin inversion and Plio-Quaternary stress field}

Basin inversion has received considerable interest, fundamentally because it can play an important role in the development of hydrocarbon traps (e.g., Cooper and Williams, 1989; Turner and Williams, 2004) and naturally fracture reservoirs both for hydrocarbon (Jolley et al., 2007) or geothermal systems (Maffucci et al., 2015). Previous discussions have focused on the role played by inherited structures in localizing subsequent contractional deformation (Cooper et al., 1989; Buchanan and Buchanan, 1995; Sibson, 1995). Both twoand three-dimensional approach studies analyze the control of previous normal faults on reverse fault orientation (Jackson, 1980; Buchanan and Buchanan, 1995), ramp localiza- tion (Tavarnelli, 1996a, 1996b; Butler et al., 2006), and segmentation of thrust belts (Marshak, 2004; Butler et al., 2006). During the last two decades, particular attention was devoted not only to the geometry and kinematics of inversion, but also to questions on mechanics (Lowell, 1995; Sandiford, 1999; Erickson et al., 2001; Cloetingh and Ziegler, 2007; Bada et al., 2007). Nowadays, there is a good agreement that the degree of reactivation of the inherited normal fault is controlled by the geometry and orientation relative to principal stress axes (Kelly et al., 1999; Dubois et al., 2002), frictional properties of the fault and pore pressure (Sibson, 1995). Although many studies propose the localization of subsequent strain along pre-existing fault planes, Tavarnelli et al. (2001) pointed out that sequential reactivation occurs due to progressive widening of the fault zone through time as a result of strain-hardening fault-rock behavior during subsequent deformation events.

Traditional studies of the Neogene-Quaternary evolution of the Cuyo Basin have assumed that the compressional regime, related to the eastward migration of the Andean thrust front, induced tectonic inversion of the principal Triassic depocenters by reactivation of master faults (Dellapé and Hegedus, 1995). The interpretation of the Cenozoic structural style of the basin has varied through time, from thinskinned tectonics without involvement of inherited Triassic faults (Bettini, 1980; Sarewitz, 1988; Figueroa and Ferraris, 1989) to complete tectonic inversion of pre-existing normal faults (Legarreta et al., 1992; Dellapé and Hegedus, 1995). A recent study postulates the mixed mode for the tectonic inversion, with contractional reactivation of pre-existing normal faults, such as the Anchayuyo Norte fault, and generation of new faults with the advance of contractional deformation in the Frontal Cordillera towards the foreland (Zencich et al., 2008). While the Cuyo Basin inversion during the Andean orogeny is nowadays accepted, the mechanisms by which this is achieved remain controversial. In previous works, the amount of inversion has been typically provided by two-dimensional insights into the geometric relationship between inversion structures and associated rift-related normal faults. These previous analyses do not take into account how inversion is accommodated along strike and the reason why some master fault segments are reactivated while others having the same attitude and orientation are not. In the previous sections we show that the master fault of the Cacheuta sub-basin was inverted only in its central and southern sectors, while the northern segments remain unaffected by the Andean orogeny. A key observation is that second-order normal faults, such as Chañares Sur and Cruz Negra, located in the southern domain, are in net extension, suggesting that reverse reactivation of these faults did not occur during inversion. An alternative interpretation that agrees with our kinematic model is that reactivation did occur but with a strikeslip movement instead of reverse.

Our stress field model shows a continuous southward change in the stress regime from reverse through strike-slip- 

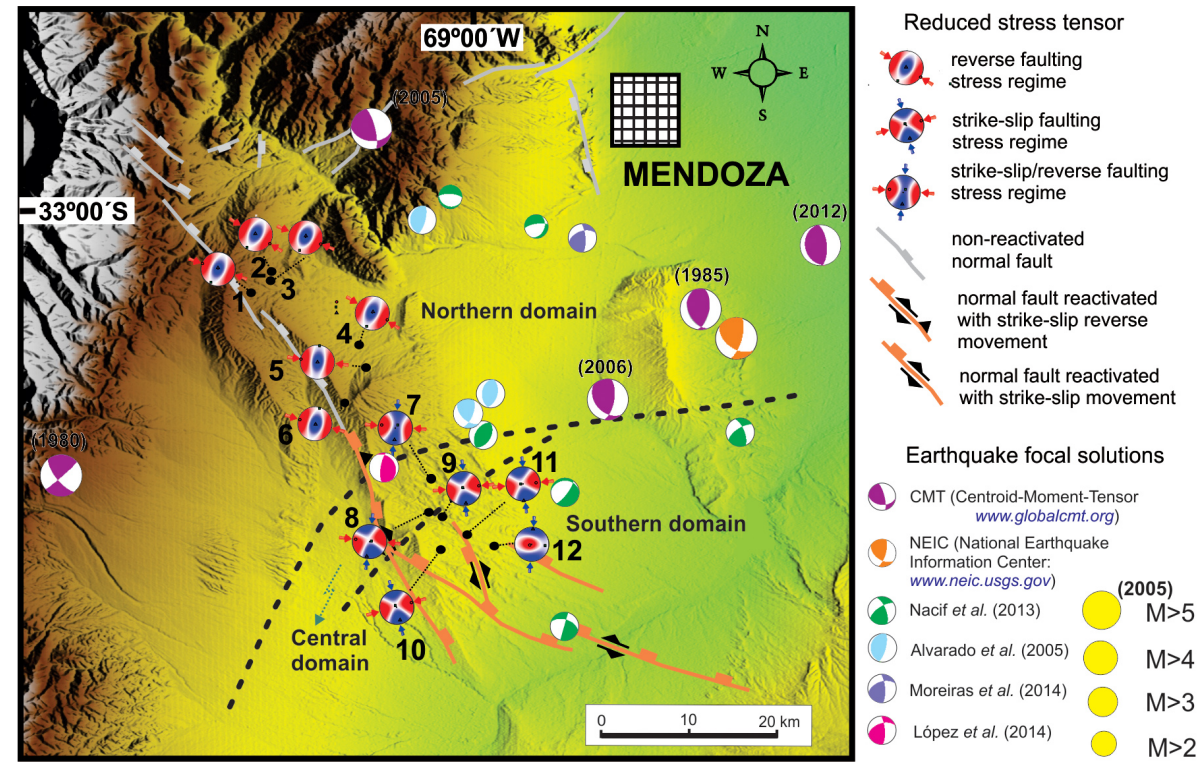

Figure 12. Dynamic analysis results (reduced stress tensors), compared with earthquake focal mechanisms obtained from CMT, NEIC, Alvarado et al. (2005), Nacif et al. (2013), López et al. (2014) and Moreiras et al. (2014). Notice the northern domain is governed by reverse faulting stress regime and compressional focal mechanisms, especially for the biggest earthquakes. To the south, seismicity abruptly vanishes, and the stress regime corresponds to a strike-slip faulting one.

reverse to strike-slip faulting, with a suggested occurrence of stress permutation between $\sigma_{2}$ and $\sigma_{3}$ in the central domain of the sub-basin.

Our slip tendency analysis indicates that the NNW-striking master fault is more likely to slip under reverse/strike-slip and strike-slip faulting regimes than under a compressive regime. The strike-slip faulting regime can reactivate relatively high-angle normal faults as strike-slip and oblique-slip faults; under a compressional stress field, pre-existing normal faults tend to lock, consistent with field and subsurface data (Fig. 12). In this regard, we propose a three-dimensional insight into the relationship of the basin inversion and the Andean stress field.

\section{Conclusions}

The Cenozoic evolution of the Cacheuta sub-basin of the Triasic Cuyo rift basin was governed by its surrounding PlioQuaternary stress field and was highly sensitive to variations in the orientation and relative values of the principal stress axes. The structural architecture of the sub-basin corresponds to a NNW-trending trough with synrift space created by movement along the Higueritas and Anchayuyo Norte normal faults. We have demonstrated that inversion in the sub-basin is dominated by folding, and strike-slip-reverse and pure strike-slip reactivation of rift-related normal faults.

The results of this study indicate that the foreland deformation along the southern transitional zone between flatslab and normal subduction segments $\left(33-33^{\circ} 30^{\prime} \mathrm{S}\right)$ shows marked and rapid changes in structural style and a spa- tial change in the Plio-Quaternary stress field. The structural styles vary from thick-skinned, newly created PlioQuaternary thrusts in the northern domain, essentially controlled by the advance of the Pliocene thrust front into the foreland area, to inverted pre-existing normal faults in the central and southern domains with the strike-slip-reverse reactivation of the Tupungato half-graben master fault and pure strike-slip reactivation of the Chañares Sur and Cruz Negra pre-existing normal faults.

Our Plio-Quaternary stress analysis indicates a spatial shift from reverse faulting stress field in the northern domain to strike-slip faulting stress field in the southern domain. The boundary between regions of different structural style is well defined and coincides with the Cienaguita transpressional fault $\left(\sim 33^{\circ} 16^{\prime} S\right)$. Pure compression prevails in the northern domain (33-33 $\left.16^{\prime} \mathrm{S}\right)$, with a WNW orientation of $\mathrm{SH}_{\max } / \sigma_{1}$ from the late Pliocene to the present. A strikeslip faulting regime prevails in the southern domain $\left(33^{\circ} 19^{\prime}-\right.$ $33^{\circ} 30^{\prime} \mathrm{S}$ ), with a WNW-oriented $\mathrm{SH}_{\max } / \sigma_{1}$ and vertically oriented $\sigma_{2}$ from the late Pliocene to the present. A $\sigma_{2} / \sigma_{3}$ permutation is interpreted to occur along the central domain, which represents a transitional zone between pure reverse to pure strike-slip deformation.

We conclude that the likelihood that rift-related master fault segments reactivate during the advance of the PlioQuaternary thrust front was determined by their orientation and geometry relative to the direction of $\mathrm{SH}_{\max }$, as well as the orientation and relative magnitudes of the principal stress axes. 


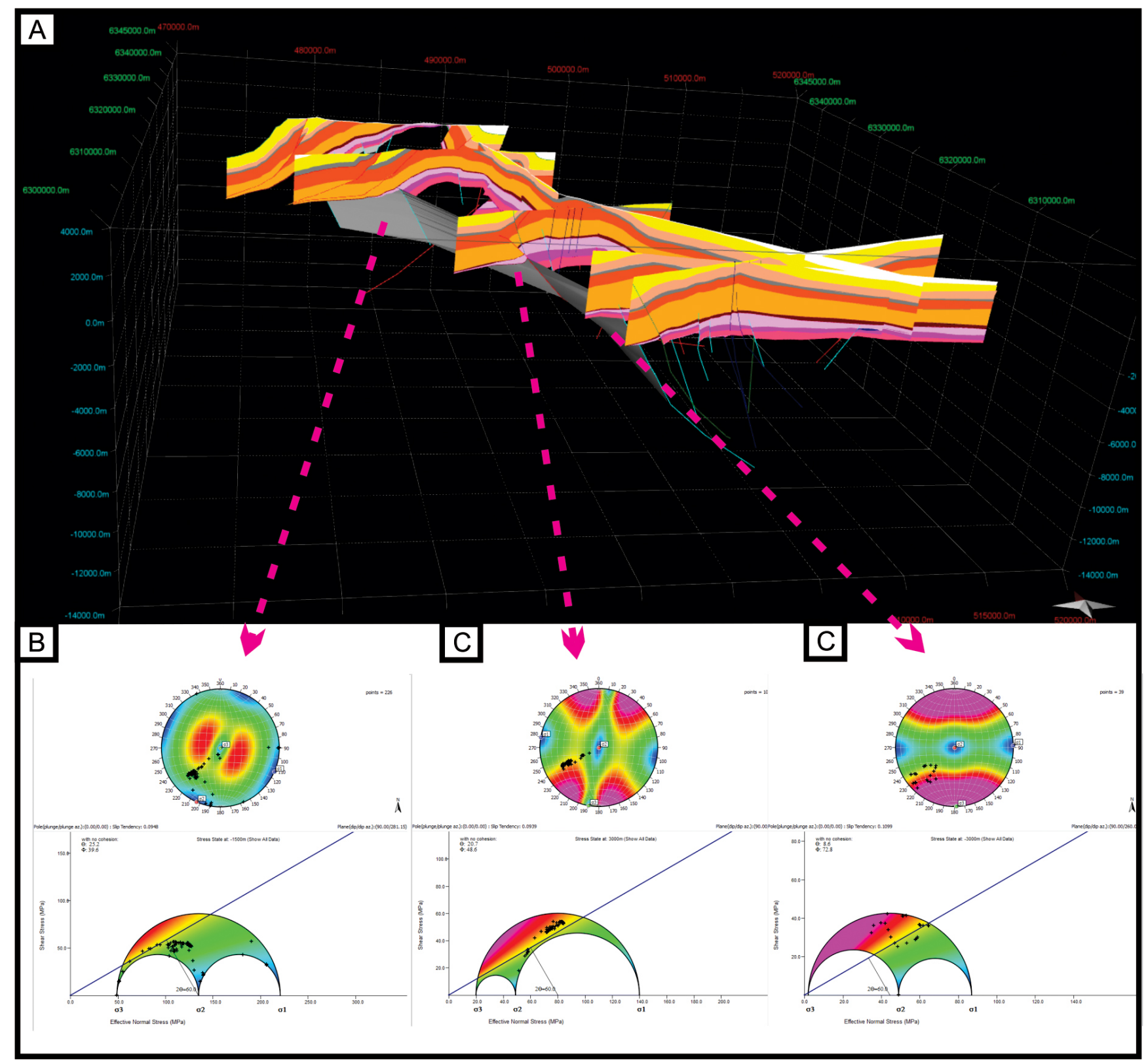

Figure 13. (a) 3-D model of the Cacheuta sub-basin area. The Triassic master fault is in grey. (b-d) Slip tendency analysis of the different segments - northern, central and southern - composing the Higueritas and Anchayuyo Norte master faults, for values of pore overpressure $=20 \mathrm{MPa}, \mu=0.6$ and $\sigma_{1} / \sigma_{3}=3.1$. The NNW-striking master fault (grey plane) is more likely to slip under reverse/strike-slip (central domain - c) and strike-slip (southern domain - d) faulting regimes than under a reverse faulting regime (northern domain - b).

Reactivation of previous normal faults under reverse/strike-slip to strike-slip faulting regimes, instead of reverse faulting regime as has previously been assumed, may have a major influence on petroleum prospectivity in the area.

The Supplement related to this article is available online at doi:10.5194/se-6-747-2015-supplement.
Acknowledgements. This research was supported by grants from the CONICET (PIP 638) and the Agencia de Promoción Científica y Tecnológica (PICT 2011-1079) to L. Giambiagi, S. M. Moreiras and J. Mescua. We would like to acknowledge the academic license of MOVE from Midland Valley Inc. and the T-TECTO 3.0 Professional academic license to IANIGLA. E. Tavarnelli and S. Corrado are sincerely thanked for their critical and helpful comments and suggestions.

Edited by: F. Rossetti 


\section{References}

Ahumada, E. A. and Costa C. H.: Antithetic linkage between oblique Quaternary thrusts at the Andean front, Argentine Precordillera, J. S. Am. Earth. Sci., 28, 207-216, doi:10.1016/j.jsames.2009.03.008, 2009.

Allmendinger, R. W.: FaultKinWinFull versión 1.2.2. A program for analyzing fault slip data for Windows ${ }^{\mathrm{TM}}$ computers, available at: http://www.geo.cornell.edu/geology/faculty/RWA/programs. html (last access: 18 June 2015), 2001.

Alvarado, P., Beck, S., Zandt, G., Araujo, M., and Triep, E.: Crustal deformation in the south central Andes backarc terranes as viewed from regional broadband seismica waveform modeling, Geophys. J. Int., 60, 580-598, 2005.

Angelier, J.: Determination of the mean principal directions of stresses for a given fault population, Tectonophysics, 56, 17-26, 1979.

Ávila, J. N., Chemale, F., Mallmann, G., Borba, A. W., and Luft, F. F.: Thermal evolution of inverted basins: Constraints from apatite fission track thermochronology in the Cuyo Basin, Argentine Precordillera, Radiat Meas., 39, 603-611, 2005.

Bada, G., Horváth, F., Dövenyi, P., Szafián, F., Windhoffer, G., and Cloetingh, S.: Present-day stress field and tectonic inversion in the Pannonian basin, Global Planet Change, 58, 165-180, 2007.

Bettini, F. H.: Nuevos conceptos tectónicos del centro y borde occidental de la Cuenca Cuyana, Asoc. Geol. Argentina Rev., 35, 579-581, 1980.

Buchanan, J. G. and Buchanan, P. G.: Basin Inversion, J. Geol. Soc. London, Spec. Public., 88, 596 pp., 1995.

Butler, R. W. H., Tavarnelli, E., and Grasso, M.: Structural inheritance in mountain belts: An Alpine-Apennine perspective, J. Struct. Geol., 28, 1893-1908, 2006.

Cahill, T. and Isacks, B. L.: Seismicity and Shape of the Subducted Nazca Plate, J. Geophys. Res., 97, 17503-17529, 1992.

Caminos, R.: Geología de la vertiente oriental del Cordón del Plata, Cordillera Frontal de Mendoza, Asoc. Geol. Argentina Rev., 20, 351-392, 1965

Casa, A. L., Borgnia, M., and Cortés, J. M.: Evidencias de deformación pleistocena en el sistema de falla de La Carrera $\left(32^{\circ} 40^{\prime}\right.$ $\left.33^{\circ} 15^{\prime} \mathrm{LS}\right)$, Cordillera Frontal de Mendoza, Asoc. Geol. Argentina, Rev., 67, 91-104, 2010.

Charrier, R.: El Triásico de Chile y regiones adyacentes de Argentina: una reconstrucción paleogeográfica y paleoclimática: Comunicaciones, 26, 1-37, 1979.

Charrier, R., Baeza, O., Elgueta, S., Flynn, J. J., Gans, P., Kay, S. M., Muñóz, N., Wyss, A. R., and Zurita, E.: Evidence for Cenozoic extensional basin development and tectonic inversion south of the flat-slab segment, southern Central Andes, Chile $\left(33^{\circ}-\right.$ $36^{\circ}$ S.L.), J. S. Am. Earth Sci., 15, 117-139, 2002.

Chiaramonte, L., Ramos, V. A., and Araujo, M.: Estructura y sismotectónica del anticlinal Barrancas, Cuenca Cuyana, provincia de Mendoza, Asoc. Geol. Argentina Rev., 55, 309-336, 2000.

Cloetingh, S. and Ziegler, P. A.: Tectonic model for the evolution of sedimentary basins, in: Crustal and Lithosphere Dynamics, Elsevier, edited by: Schubert, G., Treatise on Geophysics, 485-611, 2007

Cooper, M. A. and Williams, G. D., Inversion tectonics, J. Geol. Soc. London, Spec. Public., 44, 375 pp., 1989.

Cooper, M. A., Williams, G. D., de Graciansky, P. C., Murphy, R. W., Needham, T., de Paor, D., Stoneley, R., Todd, S. P., Turner,
J. P., and Ziegler, P. A.: Inversion tectonics - a discussion, in: Inversion tectonics, edited by: Cooper, M. A. and Williams, G. D., J. Geol. Soc. London, Spec. Public., 44, 335-347, 1989.

Dellapé, D. and Hegedus, A.: Structural inversion and oil occurrence in the Cuyo basin of Argentina, in: Petroleum basins of South American, edited by: Tankard, A. J., Suárez, R. and Welsink, H. J., AAPG Memoir, 62, 359-367, 1995.

Dubois, A., Odonne, F., Massonnat, G., Lebourg, T., and Fabre, R.: Analogue modeling of fault reactivations: tectonic inversion and oblique remobilization of grabens, J. Struct. Geol., 24, 17411752, 2002.

Erickson, S. G., Strayer, L. M., and Suppe, J.: Mechanics of extension and inversion in the hanging walls of listric normal faults, J. Geophys. Res., 106, 26655-26670, 2001.

Figueroa, D. E. and Ferraris, O. R.: Estructura del margen oriental de la Precordillera mendocino-sanjuanina, in: Proceedings of the 1st Congreso Nacional de Exploración de Hidrocarburos, 1, 515 529, 1989.

Folguera, A., Etcheverria, M., Pazos, P., Giambiagi, L., Cortés, J. M., Fauqué, L., Fusari, C., and Rodriguez, M. F.: Descripción de la Hoja Geológica Potrerillos (1 : 100 000), Subsecretaría de Minería de la Nación, Dirección Nacional del Servicio Geológico, 262 pp., 2001

García, V. H. and Casa, A. L.: Quaternary tectonics and potential seismic hazard of the Andean retrowedge between $33^{\circ}$ and $34^{\circ} \mathrm{S}$ in: Geodynamic Processes in the Andes of Central Chile and Argentina, J. Geol. Soc. London, Spec. Public., 399, 311-327, doi:10.1144/SP399.14, 2015.

Giambiagi, L., Ramos, V. A., Godoy, E., Alvarez, P. P., and Orts, S.: Cenozoic deformation and tectonic style of the Andes, between $33^{\circ}$ and $34^{\circ}$ South Latitude, Tectonics, 22, 1041, doi:10.1029/2001TC001354, 2003.

Giambiagi, L., Mescua, J., Bechis, F., Martínez, A., and Folguera A.: Pre-Andean deformation of the Precordillera southern sector, Southern Central Andes, Geosphere, 7, 1-21, 2011.

Giambiagi, L., Mescua, J., Bechis, F., Tassara, A., and Hoke, G.: Thrust belts of the Southern Central Andes: Along-strike variations in shortening, topography, crustal geometry, and denudation, Geol. Soc. Am. Bull., 124, 1339-1351, 2012.

Giambiagi, L., Mescua, J., Heredia, N., Farías, P., García Sansegundo, J., Fernández, C., Stier, S., Pérez, D., Bechis, F., Moreiras, S. M., and Lossada, A.: Reactivation of Paleozoic structures during Cenozoic deformation in the Cordón del Plata and Southern Precordillera ranges (Mendoza, Argentina), J. Iber. Geol., 40, 309-320, 2014.

Godoy, E., Yáñez, G., and Vera, E.: Inversion of an Oligocene volcano-tectonic basin and uplift of its superimposed Miocene magmatic arc, Chilean Central Andes: first seismic and gravity evidence, Tectonophysics, 306, 217-326, 1999.

Hoke, G., Graber, N., Mescua, J., Giambiagi, L., Fitzgerald, P. and Metcalf, J.: Near pure surface uplift of the Argentine Frontal Cordillera: Insights from (U-Th)/He thermochronology and geomorphic analysis, in: Geodynamic Processes in the Andes of Central Chile and Argentina, J. Geol. Soc. London, Spec. Public., 399, 383-399, doi:10.1144/SP399.14, 2015.

INPRES catalog, available at: http://www.inpres.gov.ar/ seismology/sismicidad.html, last access: 18 June 2015.

Irigoyen, M. V., Buchan, K. L., and Brown, R. L.: Magnetostratigraphy of Neogene Andean foreland-basin strata, lat $33^{\circ} \mathrm{S}$, Men- 
doza Province, Argentina, Geol. Soc. Am. Bull., 112, 803-816, 2000.

Jackson, J. A.: Reactivation of basement faults and crustal shortening in orogenic belts, Nature, 283, 343-346, 1980.

Jolley, S. J., Barr, D., Walsh, J. J., and Knipe, R. J.: Structurally complex reservoirs, J. Geol. Soc. London, Spec. Publ., 292, 124, doi:10.1144/SP292.1, 2007.

Jones, D.: Thickness map of the Cacheuta Formation. Map. YPF, 1992.

Jordan, T. E., Isacks, B. L., Allmendinger, R. W., Brewer, J. A., Ramos, V. A., and Ando, C. J.: Andean tectonics related to geometry of subducted Nazca plate, Geol. Soc. Am. Bull., 94, 341361, 1983.

Jordan, T. E., Burns, M., Veiga, R., Pángano, F., Copeland, P., Kelley, S., and Mpodozis, C.: Extension and basin formation in the southern Andes caused by increased convergence rate: A midCenozoic trigger for the Andes, Tectonics, 20, 308-324, 2001.

Kelly, P. G., Peacock, D. C., Sanderson, D. J., and McGurk, A. C.: Selective reverse-reactivation of normal faults, and deformation around reverse-reactivated faults in the Mesozoic of the Somerset coast, J. Struct. Geol., 21, 493-509, 1999.

Kokogian, D. A. and Mancilla, O. H.: Análisis estratigráfico secuencial de la cuenca Cuyana, in: Cuencas Sedimentarias Argentinas, edited by: Chebli, G. and Spalletti, L., Universidad Nacional de Tucumán, Serie de correlación Geológica 6, 201, 169 pp., 1989.

Kokogian, D. A., Fernández Seveso, F., and Mosquera, A.: Las secuencias sedimentarias triásicas, in: Proceedings of the 12th Congreso Geol. Arg., Mendoza, Argentina, 65-78, 1993.

Legarreta, L., Kokogian, D. A., and Dellapé, D.A.: Estructuración terciaria de la Cuenca Cuyana: ¿Cuánto de inversión tectónica?, Asoc. Geol. Argentina, Rev., 47, 83-86, 1992.

Llambías, E., Quenardelle, S., and Montenegro, T.: The Choiyoi Group from central Argentina: a subalkaline transitional to alkaline association in the craton adjacent to the active margin of the Gondwana continent, J. S. Am. Earth Sci., 18, 243-257, 2003.

López, L., Sánchez, G., and Araujo, M.: Mecanismos focales de eventos de magnitud Mw mayores o iguales a 4 correspondientes al período de tiempo entre el 01/01/2011 al 31/06/2013 para el territorio argentino, in: Proceedings of the 14th Cong. Geol. Arg., T3-14, Córdoba, Argentina, 2014.

Lowell, J. D.: Mechanics of basin inversion from worldwide examples, in: Basin Inversion, edited by: Buchanan, J. G and Buchanan, P. G., J. Geol. Soc. London, Spec. Public., 88, 39-57, 1995.

Maffucci, R., Bigi, S., Corrado, S., Chiodi, A., Di Paolo, L., Giordano, G., and Invernizzi, C.: Quality assessment of reservoirs by means of outcrop data and "discrete fracture network" models: The case history of Rosario de la Frontera (NW Argentina) geotermal sistema, Tectonophysics, 647-648, 112-131, doi:10.1016/j.tecto.2015.02.016, 2015.

Marshak, S.: Salients, recesses, arcs, oroclines, and syntaxes - a review of ideas concerning the formation of map-view curves in fold-thrust belts, in: Thrust tectonics and hydrocarbon systems, edited by: McClay, K. R., AAPG Memoir, 82, 131-156, 2004.

Mescua, J. and Giambiagi, L.: Fault inversión vs. new thrust generation: a case study in the Malargüe fold-and-thrust belt, Andes of Argentina, J. Struct. Geol., 35, 51-63, 2012.

Mescua, J., Giambiagi, L., Tassara, A., Gimenez, M., and Ramos, V. A.: Influence of pre-Andean history over Cenozoic foreland de- formation: structural styles in the Malargüe fold-and-thrust belt at $35^{\circ} \mathrm{S}$, Andes of Argentina, Geosphere, 10, 585-609, 2014.

Moratello, J. H.: Cuenca Cuyana, in: Proceeding of the 12th Congreso Geológico Argentino, Mendoza, Argentina, 367-375, 1993.

Moreiras, S. M., Giambiagi, L., Spagnotto, S., Nacif, S., Mescua, J., and Toural Dapoza, R.: El frente orogénico activo de los Andes Centrales a la latitud de la ciudad de Mendoza $\left(32^{\circ} 50^{\prime}-33^{\circ} \mathrm{S}\right)$, Andean Geol., 41, 342-361, 2014.

Morris, A., Ferrill, D. A., and Henderson, D. B.: Slip-tendency analysis and fault reactivation, Geology, 24, 275-278, 1996.

MOVE software from Midland Valley Exploration Ltd., available at: http://www.mve.com, last access: 18 June 2015.

Mpodozis, C. and Ramos, V. A.: The Andes of Chile and Argentina, in: Geology of the Andes and its relation to hydrocarbon and mineral resources, edited by: Ericksen, G. E., Cañas, M. T., and Reinemund, J. A., Circum-Pacific Council for Energy and Mineral Resources, Ear. Sc. Series, 11, 59-90, 1989.

Nacif, S., Triep, E., Furlani, R., and Spagnotto, S.: Stripe of normal mechanisms for crustal earthquakes $\mathrm{M} \leq 3.5$ flanking the western side of the thrust front zone in the Andes backarc, Natural Science, 5, 18-26, doi:10.4236/ns.2013.58A1003, 2013.

Ramos, V. A. and Folguera, A.: Tectonic evolution of the Andes of Neuquén: Constraints derived from the magmatic arc and foreland deformation, in: The Neuquén basin: a case study in sequence stratigraphy and basin dynamics, edited by: Veiga, G., Spalletti, L., Howell, J. A., and Schwarz, E., 252, 15-35, J. Geol. Soc. London, Spec. Public., 2005.

Ramos, V. A. and Kay, S.: Triassic rifting and associated basalts in the Cuyo basin, central Argentina, Geol. S. Am. S., 265, 79-91, 1991.

Ramos, V. A., Cristallini, E., and Pérez, D.: The Pampean flat-slab of the Central Andes, J. S. Am. Earth Sci., 15, 59-78, 2002.

Rolleri, E. D. and Fernández Garrasino, C.: Comarca septentrional de Mendoza, II Simposio de Geología Regional Argentina, Academia Nacional de Ciencias, Córdoba, Argentina, 1, 771809, 1979.

Rolleri, E. O. and Criado Roque, P.: La cuenca triásica del norte de Mendoza, in: Proceeedings of the 3nd Jornadas Geológicas Argentinas, Comodoro Rivadavia, Argentina, 1-76, 1968.

Sandiford, M.: Mechanics of basin inversion, Tectonophysics, 305, 109-120, 1999.

Sarewitz, D.: High rate of Late Cenozoic custal shortening in the Andean foreland, Mendoza province, Argentina, Geology, 16, 1138-1142, 1988.

Schmidt, S., Hetzel, R., Mingorance, F., and Ramos, V. A.: Coseismic displacements and Holocene slip rates for two active thrust faults at the mountain front of the Andean Precordillera $\left(\sim 33^{\circ} \mathrm{S}\right)$, Tectonics, 30, TC5011, doi:10.1029/2011TC002932, 2011.

Sibson, R. H.: Selective fault reactivation during basin inversion: potential for fluid redistribution through fault-valve action, in: Basin Inversion, edited by: Buchanan, J. G. and Buchanan, P. G., J. Geol. Soc. London, Spec. Public., 88, 3-19, 1995.

Stahlschmidt, E.: Geología del Braquianticlinal de la Cienaguita, map, Petrolera San Jorge, 1985.

T-TECTO software by Jure Zaholar, available at: http://www2. arnes.si/ jzaloh/t-tecto_homepage.htm, last access: 17 June 2015. 
Tavarnelli, E.: Tethyan heritage in the development of the Neogene Umbria-Marche fold-and-thrust belt, Italy: a 3-D approach, Terra Nova, 8, 470-478, 1996a.

Tavarnelli, E.: The effects of pre-existing normal faults on thrust ramp development: An example from the northern Apennines, Italy, Int. J. Earth Sci., 85, 363-371, 1996b.

Tavarnelli, E., Decandia, F. A., Renda, P., Tramutoli, M., Gueguen, E., and Alberti, M.: Repeated reactivation in the ApennineMeghrebide system, Italy: a posible example of fault-zone weakening?, in: The Nature and Tectonic Significance of fault Zone Weakening, edited by: Holdsworth, R. E., Strachan, R. A., Maglouglin, J. F., and Knipe, R. J., J. Geol. Soc. London, Spec. Public., 186, 273-286, 2001.

Tassara, A. and Echaurren, A.: Anatomy of the Andean subduction zone: 3-D density model upgraded and compared against global models, Geophys. J. Int., 189, 161-168, doi:10.1111/j.1365246X.2012.05397.x, 2012.

Tassara, A., Giambiagi, L., and Gerbault, M.: Soporte termomecánico del plateau Altiplano-Puna, in: Proceedings of the 19th Congreso Geológico Argentino, Córdoba, Argentina, Electronic files, 2014.
Turner, J. P. and Williams, C. A.: Sedimentary basin inversion and intra-plate shortening, Earth-Sci. Rev., 65, 277-304, 2004.

Uliana, M. A. and Biddle, K.: Mesozoic-Cenozoic paleogeographic and geodynamic evolution of southern South America, Revista Brasileira De Geociências, 18, 172-190, 1988.

Uliana, M., Arteaga, M., Legarreta, L., Cerdán, L., and Peroni, G.: Inversion structures and hydrocarbon occurrence in Argentina, in: Basin Inversion, edited by: Buchanan, J. G. and Buchanan, P. G., J. Geol. Soc. London, Spec. Public., 88, 211-233, 1995.

Zalohar, J. and Vrabec, M.: Paleostress analysis of heterogeneous fault-slip data: the Gauss method, J. Struct. Geol., 29, 17981810, 2007.

Zavattieri, A. M. and Prámpano, M. B.: freshwater algae from the Upper Triassic Cuyana basin of Argentina: Palaeoenvironmental implications, Palaeontology, 49, 1185-1209, 2006.

Zencich, S., Villar, H. J., and Boggetti, D.: Sistema petrolero Cacheuta-Barrancas de la Cuenca Cuyana, provincial de Mendoza, Argentina, in: Sistemas Petroleros de las Cuencas Andinas, in: Proceedings of the 7th Congreso de Exploración y Desarrollo de Hidrocarburos, Mar del Plata, Argentina, edited by: Cruz, C., Rodríguez, J., Hechen, J., and Villar, H. J., 109-134, 2008. 